九州大学学術情報リポジトリ

Kyushu University Institutional Repository

\title{
Study on the Effectiveness of Ozonation Technique in Preventing Scale Precipitation on Closed System Cooling Towers
}

\section{I. Alhamid}

Department of Mechanical Engineering, Faculty of Engineering, Universitas Indonesia

\section{S. Bismo}

Department of Chemical Engineering, Faculty of Engineering, Universitas Indonesia

I. T. Ramadhan

Department of Mechanical Engineering, Faculty of Engineering, Universitas Indonesia

A. Yatim

Department of Mechanical Engineering, Faculty of Engineering, Universitas Indonesia

https://doi.org/10.5109/2321013

出版情報 : Evergreen. 6 (1)，pp.65-70，2019-03. 九州大学グリーンアジア国際リーダー教育センター バージョン：

権利関係 : 


\title{
Study on the Effectiveness of Ozonation Technique in Preventing Scale Precipitation on Closed System Cooling Towers
}

\author{
M.I. Alhamid ${ }^{1, *}$, S. Bismo ${ }^{2}$, I.T. Ramadhan ${ }^{1}$, A. Yatim ${ }^{1}$ \\ ${ }^{1}$ Department of Mechanical Engineering, Faculty of Engineering, Universitas Indonesia, Indonesia \\ ${ }^{2}$ Department of Chemical Engineering, Faculty of Engineering, Universitas Indonesia, Indonesia
}

*Author to whom correspondence should be addressed,

E-mail: mamak@eng.ui.ac.id

(Received March 8, 2019; accepted March 26, 2019).

\begin{abstract}
A cooling tower is a unit that helps the process of heat dissipation. Thus, thermal effectiveness is a vital variable for cooling tower performance. Scale precipitation can obstruct thermal effectiveness of the heat exchange unit due to its natural high thermal resistance properties. The ozonation process is expected to decrease the potential of scale precipitation thereby improving cooling tower thermal performance. Cooling water is circulated from the tower before ozone and UV rays are applied. This study aims to determine the characteristics of the effects of ozonation on the overall thermal fouling resistance of forced draft type - counter flow - closed system cooling towers and the quality of water circulation by using the Practical Ozone Scaling Index and Langelier Saturation Index methods. Water quality from closed system cooling towers is determined by conducting laboratory tests. The results obtained from this study indicate that when ozone is present the overall thermal tower resistance of the closed system cooling towers is reduced by 7 x10-6 m2K/W. Ozone can also improve the water quality of closed system cooling towers.
\end{abstract}

Keywords: Cooling Tower; Ozonization Technique; Scale Prevention; Water Quality Improvement.

\section{Introduction}

Evaporative cooling systems have been widely used in the industrial sector to remove heat from various process systems, as well as in the modern building sector for air conditioning purposes. The coolant works by releasing heat generated from the condensation process of a system and in general water is used as a coolant, i.e. it is a heat exchanger fluid to remove heat from various systems $^{1-5)}$. In principle, hot fluid in the system is channeled to the cooling tower and recirculated after dissipating heat into the atmosphere ${ }^{6)}$. Several characteristics of cooling tower performances have been reported $^{7-20)}$

Data in some industries show that ozone can act as a descaling and anti-fouling agent ${ }^{21)}$ to minimize the formation of scale in the system. The premise is that ozone oxidizes the microorganism layer which functions as a binding agent for scalant mineral deposits on the surface of the cooling tower system. By reducing the buildup of scale on the tower cooling system a higher heat transfer rate can be achieved and cooling tower performance is optimal ${ }^{22}$. This in depth study analyzes the level of ozone effectiveness in preventing the formation of scalant deposits on closed system cooling towers.

Pryor and Fisher (1993) $)^{23)}$ have proven that conventional indices (for example, LSI) are used to forecast calcium carbonate precipitation in the waters of conventionally treated cooling towers, rather than as precise indicators of potential scale in the ozonized system. Using a practical approach, Practical Ozone Scaling Index (POSI), the POSI equation predicts the upper limit of conductivity operations in other ozonated systems ${ }^{23)}$. The use of conventional indices cannot accurately predict how many cycles can be operated before scale concentration begins to build up in the ozonated cooling system.

Water quality analysis results can provide electrical conductivity values for cooling towers and MU water. However, the POSI equation calculates the maximum possible number of cycles of concentration (based on conductivity) that can be achieved without scaling. Based on the obtained POSI value, the maximum value of the cycle concentration of the cooling tower circulation water can be predicted, which based on the comparison of electrical conductivity.

Based on the afore mentioned research it can be concluded that the process of ozonisation is expected to 
reduce the potential for scalant precipitation which will subsequently improve the thermal performance of the cooling tower. In order to achieve this expectation, the characteristics of the effects of ozonation on the overall thermal fouling resistance of forced draft type - counter flow - closed system cooling towers and the quality of water circulation through the Practical Ozone Scaling Index and Langelier Saturation Index methods must be known first. The Langelier Saturation Index (LSI), is a parameter measure of the ability of a solution to dissolve or precipitate calcium carbonate, often used as a water corrosion indicator ${ }^{24-25)}$. Langelier's index is not directly related to corrosion, but is related to the deposition of film or scale from calcium carbonate. Conversely, when the solution does not form or deposit scale, water is considered aggressive and corrosion can occur.

Furthermore, there has been no detailed study on how the use of ozone and the effects of its scaling in a closed system cooling tower can affect and improve operation of the closed cooling tower system.

\section{Experimental Methodology}

\subsection{Experimental Design Setup}

In this study, the cooling tower located at Department of Engineering University of Indonesia, which is a closed system cooling tower with non-combined fluids crossed flow, that is used in parallel with chiller to supply cool water to the adjacent MRC building's air conditioning system. The cooling tower is made in Thailand by KUKEN Company. The specific model used is KMB-68GR series RMR13-5161 which has $442.8 \mathrm{~kW}$ cooling capacity, $68 \mathrm{~m}^{3} / \mathrm{h}$ flowrate, and $3 \mathrm{PH} 380 \mathrm{~V}$ power supply.

In addition, this cooling tower system is supported by; a Firman stainless centrifugal pump that is used to circulate water inside the cooling tower; an Aquasuper Ozone Generator to create ozone to be injected into the circulated water connected to the Mazzei Injector; and a UV-C lamp used to emit UV-C light in the disinfection process and to prolong the sustainability of ozone in water. An electrical controlling instrument such as Autonics DAQ has 8 channels for temperature measurements connected to Type K thermocouple.

\subsection{Experimental Process}

Additional water ducts were made on the closed system cooling towers to enable ozone to be injected into the cooling tower water system, then, frames or stands were made to protect research equipment from rain and waterlogging. As the equipment is located outside the closed system cooling towers, other components were installed such as additional water lines, valves, bypasses, flow meters, Mazzei injectors, UV lighting and an Ozone Generator. Checks were also needed to ensure there were no leaks from the pipe inside the additional water channel of the closed system cooling tower.

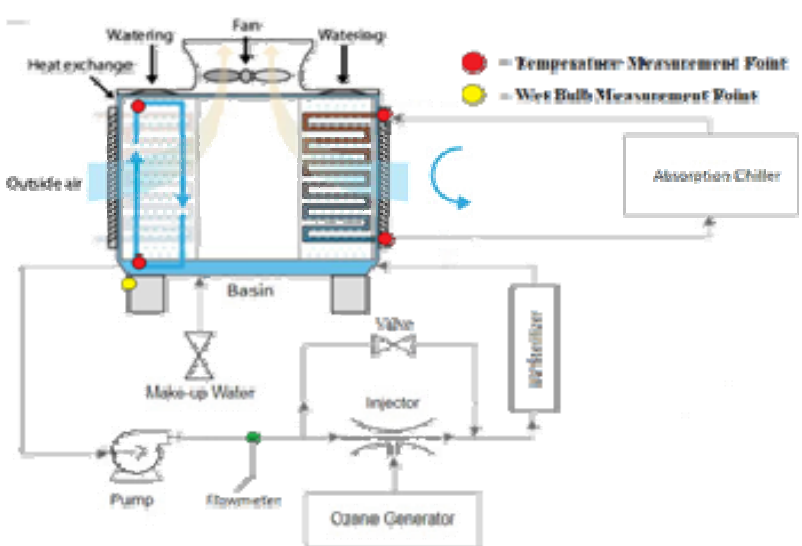

Fig. 1: Experimental design in Closed System Cooling Tower

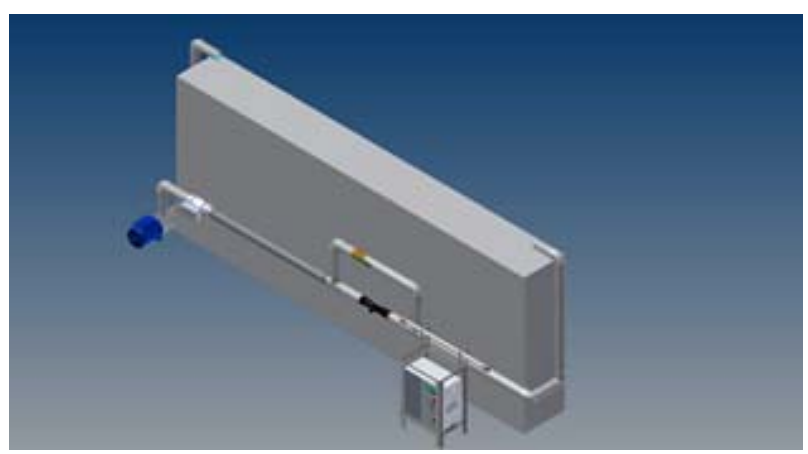

Fig. 2: Isometric Experimental Design

To begin the operation, water pump is turned on to start circulation in the additional water lines of the closed system cooling tower, the UV and Ozone Generator lights are turned on and the Ozone Generator timer is set at 120 minutes which will ensure that it will work for 120 minutes before switching off automatically. The Ozone Generator cannot work continuously and requires a break of about 1 hour to prevent the device from overheating.

Data retrieval is carried out when ozone solubility and flow from additional waterways on the closed system cooling tower are stable. Temperature values are taken at two measurement points using a type-k thermocouple that is connected to DAQ Master software.

\subsection{Experimental Testing}

\subsubsection{Ozone Production Test}

Ozone levels were determined by applying the indigo method of analyzing samples using the $\mathrm{HACH}$ colorimeter. Samples reacting with indigo reagents turn blue. The procedure for analyzing dissolved ozone concentrations was made after erlenmeyer flasks containing remazol blue samples and the ozone reagent were prepared and Aquades were put into the ozone reagent for comparison. The water from the degradation sample is added to the ozone reagent. The dissolved ozone concentration was measured using the DR-890 
colorimeter. The productivity value of the Ozone Generator is $500 \mathrm{mg} / \mathrm{l}$ Ozone.

\subsubsection{Water Quality Test}

The water quality test is carried out to observe calcium hardness, potassium hardness, silica, iron, sodium and copper content in the cooling tower water. This test was conducted in the Department of Chemistry, FMIPA and the Department of Environmental Engineering, FTUI.

\section{Results and Discussion}

\subsection{Characterization of Ozonation Effectiveness}

\subsubsection{Langelier Saturation Index}

The Langelier Saturation Index calculation uses several parameters including temperature, TDS (total dissolved solid), calcium hardness, and total alkalinity in water. These parameters are obtained from water quality tests or measurements that have been taken manually using a measuring instrument. Comparison of LSI values before and after the ozonation process is illustrated by a graph in Fig. 3.

It can be seen in the graph above that the value of LSI in pre-ozonation water is 0.973 . This value indicates that water is highly saturated by $\mathrm{CaCO}_{3}$ and scale formation can occur. However, because of the high LSI value, the water is considered to be non-corrosive. Meanwhile, in post-ozonation water, the LSI value is 0.701. The condition of the water with LSI value is almost the same as the pre-ozonation water. However, the potential for scale formation from post-ozonation water is less than the pre-ozonation water which means that post-ozonation water has the potential to become corrosive.

\subsubsection{Practical Ozone Saturation Index}

Calculation of the POSI value index is to determines the maximum value of electrical conductivity in water that can be safely circulated. Based on the POSI value, the value of the cycle concentration, generally called the Cycle of Concentration (CoC), which can be circulated on the cooling tower can be estimated. This value is determined based on several water quality parameters including $\mathrm{pH}$, electrical conductivity, calcium and magnesium hardness, sodium and chloride levels, temperature, and total alkalinity.

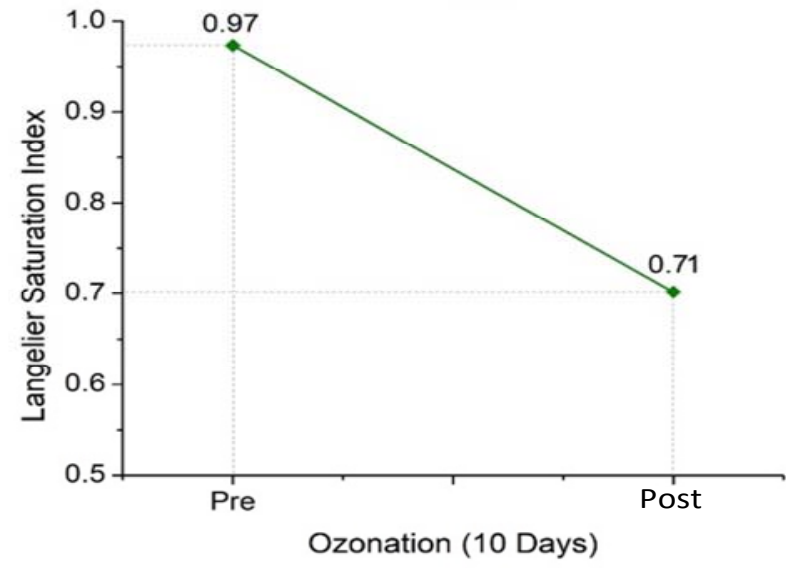

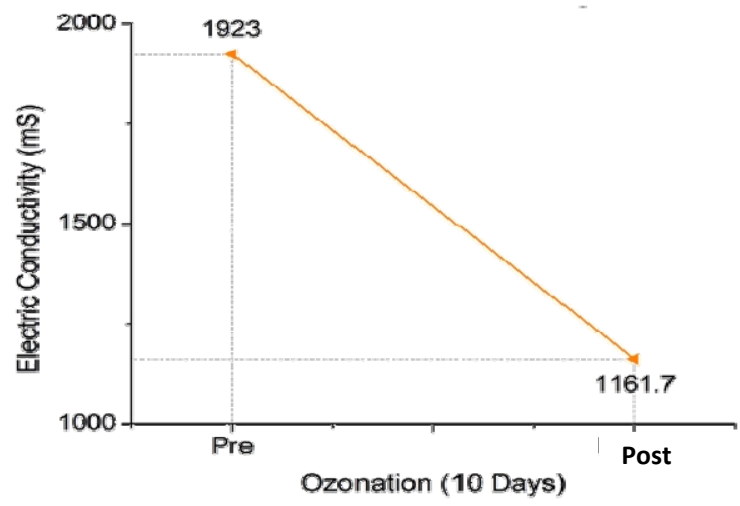

(a)

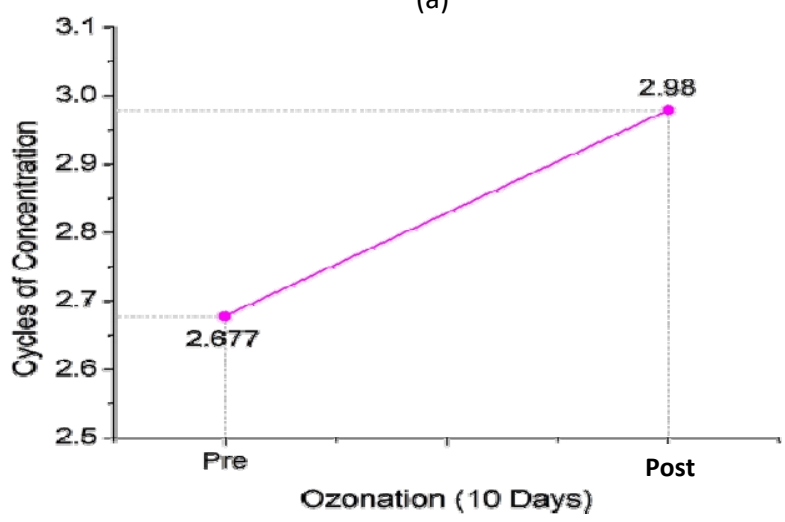

(b)

Fig. 4: (a) Comparison of POSI Value, (b) Estimated Cycle of Concentration according to POSI

Figure 4 (a) shows a comparison of the POSI values obtained by pre-ozonation and post-ozonation. The POSI value of pre-ozonation water shows a maximum electrical conductivity value of 1922.51 micro-siemens. These values indicate that water of the pre-ozonation water quality can be circulated to a concentration close to 2.5 cycles.

Meanwhile, the POSI value from post-ozonation shows a decrease in the maximum electrical conductivity value from water, when compared with POSI pre-ozonation water. However, with a POSI value of 1161.7 post-ozonation water can be used or circulated on the cooling tower to almost 3 cycles of concentration. See graph in Fig. 4 (b). It can be concluded that the ozonation process increases the number of water concentration cycles that can be used safely, without scalant precipitation caused by excessive ionic concentration.

\subsection{Water Quality Comparison}

Comparison of pre-ozonation and post-ozonation water quality shows that the ozonation process improves the water quality of cooling tower circulation. Both water values, TDS (total dissolved solids) and EC (electrical conductivity), show a declining trend. Figure 5 shows the comparison of pre- and post-ozonation water quality.

Fig. 3: Comparison of LSI Value 
The graph below shows that the relative TDS value

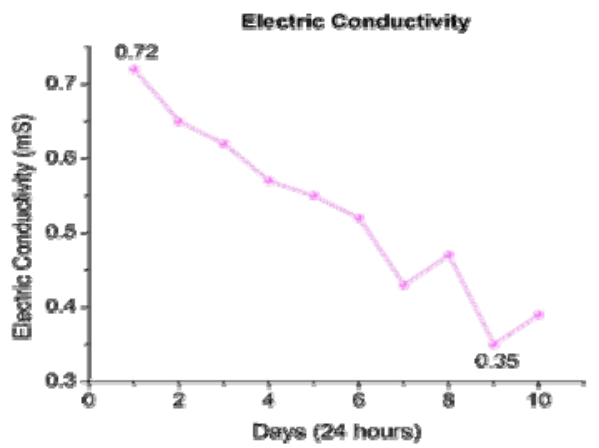

(a)

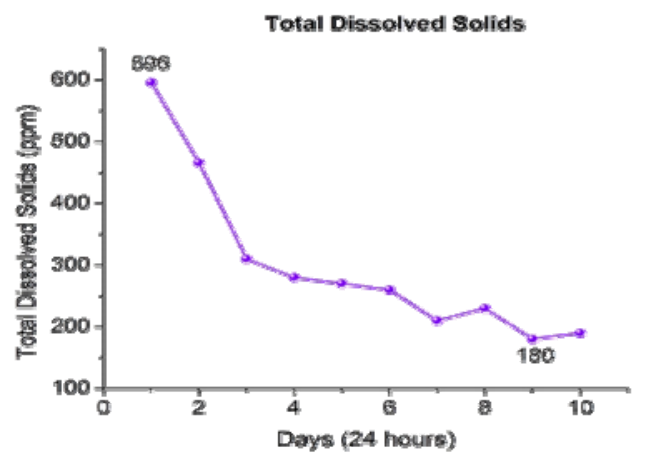

(b)

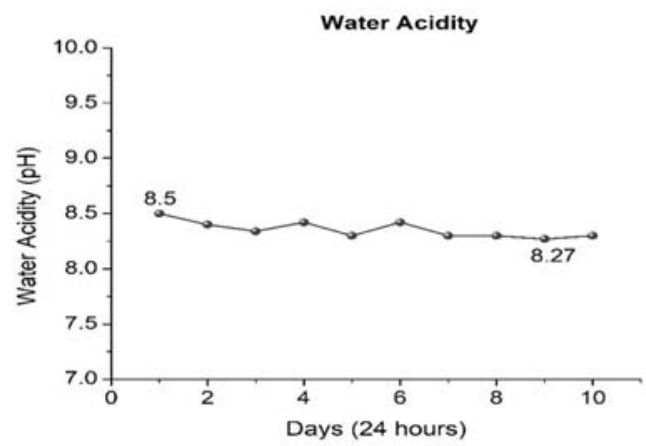

(c)

Fig. 5: Water Quality Throughout Process (a) shows TDS Value, (b) shows EC Value, and (c) shows $\mathrm{pH}$ Water Value

continues to decline during the ozonation process. Where indicates a drop in value of total solids dissolved in the water. The same characteristics are also indicated by the value of the electrical conductivity (EC) described by Fig. 5 (b).

The trend of decreasing electrical conductivity value in the water indicates a decrease in the amount of dissolved metal ions which are natural good conductors of electricity. However, looking at the $\mathrm{pH}$ variable it can be seen that ozone is considered to be less effective in balancing the acidity of the water as shown in Fig. 5 (c). The $\mathrm{pH}$ value as shown in the graph above shows unstable data. Although ozone is less effective on water $\mathrm{pH}$ treatment, the trend still shows that water $\mathrm{pH}$ will decrease in the ozonation process which concurs with the theory that ozone property is acidic and will reduce $\mathrm{pH}$ levels. Those graph of water quality data above do show some unstable and off the chart points. This is due to the fact that the cooling towers are exposed to the outside environment so they are easily affected by environmental factors such as air, rain, etc.

\subsection{Heat Transfer Effectiveness of Cooling Tower}

\subsubsection{Fouling Resistance Comparison}

In this calculation several assumptions are used, namely: hot fluid circulation is constant according to the KUKEN cooling tower specifications of 68,000 LPH; the area of heat exchange is considered constant. The last assumption is that calculations of logarithmic temperature changes assume that the DTM UI closed system cooling tower is a Crossed-Flow flow, non-combined fluids type.

Fouling Resistance calculations use several variables including changes in logarithmic temperature and total heat load. Fig. 6 shows the comparison of the values of Fouling Resistance from the cooling tower.

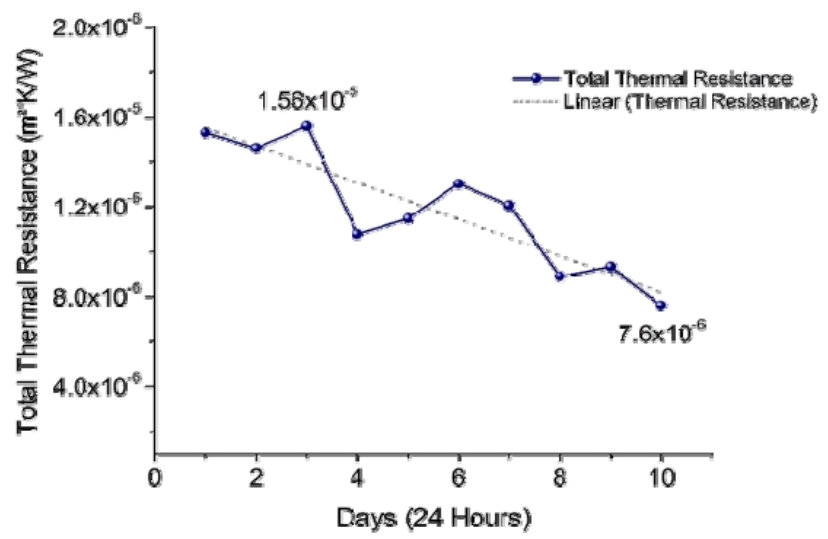

Fig. 6: Fouling Resistance Value Comparison

Based on the data and graphs obtained, the overall thermal resistance value of the cooling tower is relatively decreased but only on small amount. However, the data trend indicates that the scale which has accumulated on the cooling tower is thinning, thus the overall thermal resistance of the cooling tower is decreased. The ozonation process produces a positive tendency to improve the performance and effectiveness of thermal cooling towers by eroding the layer of scale in the heat transfer area.

\section{Conclusion}

The Langelier Saturation Index method shows that there is an increase in water quality of cooling tower circulation after the ozonation process has taken place. Circulating water potentially reduces scalant precipitation but excessive use of ozone can cause 
circulating water to become corrosive. The Practical Ozone Scaling Index method shows that the ozonation process will increase the number of cycles of concentration of circulating water without scalant precipitation due to excessive ionic water concentration. The circulating water quality test shows the characteristics of TDS, EC and water $\mathrm{pH}$ values are relatively lower. This can indicate the reduced potential for scale formation by circulating cooling tower water, and the ozonation process increases the effectiveness of heat exchange of the cooling tower due to the decrease in the total thermal resistance value of the cooling tower. These results could be an indication that the scale layer accumulated in the cooling tower begin to decrease in thickness.

\section{Acknowledgements}

The author would like to thank Directorate of Research and Community Engagements Universitas Indonesia (DRPM UI) for funding this research through the PITTA 2018 scheme with contract number 2489/UN2.R3.1/HKP.05.00/2018.

\section{References}

1) Sultan M El-Sharkaw I Miyazaki T Saha B Koyama S, Experimental Study on Carbon Based Adsorbents for Greenhouse Dehumidification, Evergreen, doi.org/10.5109/1495157

2) Cremaschi, L., Yatim, A.S., Mulugurthi, S.K. Experimental study of oil retention in microchannel type evaporators of air-source heat pump systems, International Journal of Refrigeration, $91 \mathrm{pp}$. 158-166 (2018)

3) Fuadi, Zulfa, A. Yatim, R. Rizky, N Aisyah, I. Alhamid, B. Budihardjo, and N. Putra. Chiller performance study with refrigerant R290, AIP Conference Proceedings 2062, 020061 (2019)

4) Cremaschi, L., Saad Yatim, A., Oil retention in microchannel heat exchangers of an R134a refrigeration system and effects on their energy performance and system COP, Science and Technology for the Built Environment 25(3), (2019)

5) Kosasih, Engkos Achmad, D. Prasetyo, A. Siahaan, A. Yatim, and A. Pamitran, Heat and mass transfer droplets of n-Hexane and n-Heptane towards temperature and rate of air flow rate variations, AIP Conference Proceedings 2062, 020062 (2019)

6) McNicholas, P.D., The Use of Ozone in Cooling Towers (2002)

7) Shahzad, Muhammad Wakil, Kyaw Thu, Bidyut Baran Saha, Kim Choon Ng, An Emerging Hybrid Multi-Effect Adsorption Desalination System, Evergreen, 1(02) pp. 30-36 (2014)

8) Alhamid,. M.I., S. Bismo, F. Nainggolan and A. Yatim, Analysis of the effectiveness of ozonation on corrosion and bacteria on closed system cooling towers, AIP Conference Proceedings 2062, 020046 (2019)

9) Alhamid, M.I., Bismo, S., Kelvin, R., Yatim, A., Performance analysis and water quality after ozone application in closed circuit cooling tower systems, AIP Conference Proceedings 2062, 020043 (2019)

10) Taha, Ahmed, El-Sousy K, Helles R, Helles S. Elimination of Remazole Blue-B by Advanced Oxidation Methods. Journal of Al Azhar University Gaza Vol. 8, 55-64 (2006)

11) Alaton, IA Balcioglu, DW Bahnemann. Advanced oxidation of a reactive dyebath effluent: Comparison of O3, H2O2 / UV-C and TiO2 / UV-A processes. Water Res. 36. 1143-1154 (2002)

12) Indrawati. Papers solution decolorize Remazol Brilliant Blue Using Ozone Electrolysis results. Semarang: Department of Chemical Engineering, Faculty of Engineering, University of Diponegoro (2008)

13) Karamah, E. F., S. Bismo, and W. W. Purwanto. "Significance of Acoustic and Hydrodynamic Cavitations in Enhancing Ozone Mass Transfer." Ozone: Science and Engineering 35 (6): 482-488 (2013)

14) Karamah, E. F., R. Ghaudenson, F. Amalia, and S. Bismo. "Disinfection of Escherichia Coli Bacteria using Hybrid Method of Ozonation and Hydrodynamic Cavitation with Orifice Plate.”. AIP Conference Proceedings Volume 1904, Article number 020075, 3rd International Symposium on Applied Chemistry 2017, ISAC 2017

15) Ministry of Environment. Regulation of the Minister of Environment of the Republic of Indonesia Number 5 of 2014 regarding Standard Wastewater. Jakarta (2014)

16) Sastrosudiro, BS, et al., Control Strategy of Solar Thermal Cooling System under the Indonesia Climate (2016)

17) Bott, TR, Fouling of heat exchangers. Elsevier (1995)

18) Pope, D.H., et al., The effect of ozone on Legionella pneumophila and other bacterial populations in cooling towers. Current Microbiology, 10(2): p. 89-94 (1984)

19) John, H., Cooling Towers System Guidance for Energy Operations. Kelcroft E \& M Limited p. 1-6 (1988)

20) Lezcano, I., et al., Ozone inactivation of microorganisms in water: gram positive bacteria and yeast. Ozone: science \& engineering, 23(2): p. 183-187 (2001)

21) Program, N.T.D., Ozone Treatment for Cooling Towers (1998)

22) Sung, S.-K., S.-H. Suh, and D.-W. Kim, Characteristics of cooling water fouling in a heat exchange system. Journal of mechanical science 
and technology 22(8): p. 1568-1575 (2008)

23) Pryor, A.E. and T.E. Buffum, A new practical index for predicting safe maximum operating cycles of concentration in ozonated cooling towers (1995)

24) Langelier, W.F., The analytical control of anti-corrosion water treatment. Journal (American Water Works Association) 28(10): p. 1500-1521 (1936)

25) Langelier, W.F., Chemical equilibria in water treatment. Journal (American Water Works Association) 38(2): p. 169-17 (1946) 